\title{
Long-term Effects of Restricted Root Volume and Regulated Deficit Irrigation on Peach: II. Productivity and Water Use
}

\author{
A.M. Boland, ${ }^{1}$ P.H. Jerie, ${ }^{1,4}$ P.D. Mitchell, ${ }^{2}$ and I. Goodwin ${ }^{1}$ \\ Stone and Pome Fruit Section, Institute of Sustainable Irrigated Agriculture, Tatura Centre, Department \\ of Natural Resources and Environment, Private Bag, Tatura 3616, Australia
}

D.J. Connor ${ }^{3}$

Department of Crop Production, University of Melbourne, Parkville 3052, Victoria, Australia

Additional Index wORds. Prunus persica, root confinement, stone fruits

\begin{abstract}
Individual and interactive effects of restricted root volume (RRV) and regulated deficit irrigation (RDI) on productivity and water use of peach trees [Prunus persica (L.) Batsch 'Golden Queen'] were studied over 3 years (1992-95). Trees were grown in lysimeters of five different soil volumes $\left(0.025,0.06,0.15,0.4\right.$, and $\left.1.0 \mathrm{~m}^{3}\right)$ with either full or deficit $(\mathrm{RDI})$ irrigation. In Years 3 and 4, fruit size was reduced by up to $30 \%$ on trees in the two smallest volumes. Tree water use was positively related to increasing soil volume (linear, $P<0.001$; quadratic, $P<0.011$ ) in all years ranging from 1.8 to $4.4 \mathrm{~L} \cdot \mathrm{mm}^{-1} \mathrm{E}_{\mathrm{pan}}$ in the post-RDI period of Year 2. Water use of deficit-irrigated trees was less than fully irrigated trees and there was an interaction between soil volume and irrigation treatment during RDI. Water relations did not limit growth or productivity. Tree water use was reduced under root restriction as a consequence of canopy demand rather than leaf function. Results suggest that a combination of restricted root volume and development of water stress achieve the RDI response in the Goulburn Valley, Australia.
\end{abstract}

Recent studies have indicated the effectiveness of root restriction on control of vegetative growth with no adverse effect on fruiting efficiency (Erez et al., 1992; Mandre et al., 1995; Myers, 1992). Peach trees [Prunus persica (Peach Group) 'Golden Queen'], with confined roots had yield efficiency similar to or greater than unconfined trees and began production earlier (Myers and Savelle, 1990; Williamson and Coston, 1990).

The long-term effects of restricted root volume (RRV) on vegetative growth, productivity, mineral nutrient status, water use, and water relations of an orchard must be established for its application in the field. Research is required to quantify the optimum root volume to optimize long-term productivity for a particular species.

In addition to the above effects, RRV is expected to play an important role in the RDI response. The successful application of RDI in the Goulburn Valley, Australia, may in fact be related to the relatively shallow soils in the region which both restrict root volume (Richards and Rowe, 1977a, 1977b) and allow moderate water stress to develop (Jerie et al., 1989).

The following experiment was designed to identify the separate effects of RRV and water stress on long-term growth, productivity, and water-use efficiency of peach. In addition, the interaction between the physical response to RRV and water stress associated with RDI management was studied.

Received for publication 27 July 1998. Accepted for publication 29 Sept. 1999. This research was supported by the Australian Centre for International Agricultural Research (ACIAR). We thank A.P.L. Callinan, Biometrics Services, Department of Natural Resources and Environment, for assistance with statistical analysis. The cost of publishing this paper was defrayed in part by the payment of page charges. Under postal regulations, this paper therefore must be hereby marked advertisement solely to indicate this fact.

${ }^{1}$ Horticulture irrigation scientist.

${ }^{2}$ Deceased.

${ }^{3}$ Professor.

${ }^{4}$ Stone and pome fruit section leader.

\section{Materials and Methods}

EXPERIMENTAL DeSign AND Management. The experimental design and orchard management have been described previously (Boland et al., 2000).

CANOPY COVER AND FRUIT THINNING STRATEGy. In Year 1 of the experiment, trees grew rapidly (Boland et al., 1994) and by the start of the second season (1992/93) those in the three largest volumes had filled their allotted canopy space. In that season, trees in the 0.025 and $0.06 \mathrm{~m}^{3}$ volumes had $\approx 50 \%$ and $75 \%$ canopy cover (vertical and lateral projection) respectively. At the beginning of the third growing season (1993/94) the trees in the smallest volume $\left(0.025 \mathrm{~m}^{3}\right)$ covered an estimated $75 \%$ of allotted canopy space. All trees had full canopy cover at the start of the fourth season (1994/95).

In all years, fruit thinning was based on tree size. In Year 2, thinning was based on trunk cross-sectional area (TCA) (Mitchell et al., 1983). Trees were thinned to four fruit per cubic centimeter of TCA resulting in an average number of fruit for each treatment as described in Table 1. In Year 3, thinning was based on tree canopy area with an aim to produce $50 \mathrm{t} \cdot \mathrm{ha}^{-1}$ of harvestable fruit, assuming eight fruit per kilogram. Uniform thinning was applied to all trees in Year 4 with the aim to produce $50 \mathrm{t} \cdot \mathrm{ha}^{-1}$ of harvestable fruit of a large size (seven fruit per kilogram).

Table 1. Thinning strategy for treatments in Years 2, 3, and 4. Thinning aimed to leave the specified number of fruit per tree.

\begin{tabular}{lccc}
\hline \hline & \multicolumn{3}{c}{ Fruit no./tree } \\
\cline { 2 - 4 } Treatment & Year 2 & Year 3 & Year 4 \\
\hline 1 and 2 & 15 & 120 & 140 \\
3 and 4 & 20 & 160 & 140 \\
5 and 6 & 30 & 160 & 140 \\
7 and 8 & 35 & 160 & 140 \\
9 and 10 & 40 & 160 & 140 \\
\hline
\end{tabular}


Table 2. Effect of soil volume and irrigation on fruit expansion $\left(\mathrm{cm}^{3}\right)$ in Years 2 to 4 during the regulated deficit irrigation (RDI) and post-RDI periods.

\begin{tabular}{|c|c|c|c|c|c|c|c|c|c|c|}
\hline \multirow{3}{*}{$\begin{array}{l}\text { Soil } \\
\text { vol } \\
\left(\mathrm{m}^{3}\right)\end{array}$} & \multicolumn{4}{|c|}{ Year 2} & \multicolumn{4}{|c|}{ Year 3} & & \\
\hline & \multicolumn{3}{|c|}{ RDI } & \multirow[b]{2}{*}{ post-RDI } & \multicolumn{3}{|c|}{ RDI } & \multirow[b]{2}{*}{ post-RDI } & \multicolumn{2}{|c|}{ Year 4} \\
\hline & Mean & Deficit & Full & & Mean & Deficit & Full & & RDI & post-RDI \\
\hline 0.025 & 12.3 & 9.6 & 14.9 & 53.2 & 14.4 & 13.3 & 15.4 & 67.3 & 3.7 & 54.1 \\
\hline 0.06 & 10.2 & 10.1 & 10.3 & 49.7 & 15.8 & 17.3 & 14.2 & 64.7 & 4.0 & 59.8 \\
\hline 0.15 & 11.0 & 10.9 & 11.1 & 55.0 & 15.4 & 14.7 & 16.1 & 64.7 & 4.1 & 62.6 \\
\hline 0.4 & 8.9 & 7.8 & 9.9 & 40.5 & 14.3 & 12.6 & 16.1 & 63.5 & 4.7 & 63.1 \\
\hline 1.0 & 8.7 & 8.0 & 9.4 & 36.0 & 15.3 & 15.3 & 15.3 & 70.1 & 4.0 & 58.2 \\
\hline \multicolumn{11}{|c|}{$\begin{array}{l}\text { Significance of } \\
\text { contrast ( } P \text { value })\end{array}$} \\
\hline Linear & $<0.001$ & & & $<0.001$ & 0.840 & & & 0.263 & 0.840 & 0.856 \\
\hline Quadratic & 0.027 & & & 0.192 & 0.367 & & & 0.216 & 0.367 & 0.021 \\
\hline \multicolumn{11}{|c|}{ Volume $\times$ irrigation } \\
\hline ( $P$ value $)$ & 0.021 & & & NS & 0.003 & & & NS & NS & NS \\
\hline \multicolumn{11}{|l|}{ Irrigation } \\
\hline Deficit & 9.3 & & & 45.5 & 14.6 & & & 67.3 & 4.2 & 59.6 \\
\hline Full & 11.1 & & & 48.3 & 15.4 & & & 64.8 & 4.0 & 59.5 \\
\hline $\mathrm{LSD}_{0.05}$ & 1.03 & & & NS & NS & & & NS & NS & NS \\
\hline
\end{tabular}

Productivity and water use. In Years 2, 3, and 4, four fruit per experimental tree (eight fruit per plot) were tagged and diameter measured once every 2 weeks with digital callipers. Fruit were harvested based on fruit color resulting in up to five harvests per season over a period of 2 weeks. Fruit from individual trees were counted and weighed at each harvest and mean fruit weight (MFW) was calculated.

Tree water use was determined weekly from measurements of irrigation applied and drainage. Changes in water content of the profile were negligible except for weeks when rainfall exceeded $20 \mathrm{~mm}$. Water use data were not included for these weeks. Water use was expressed as liters per millimeter of evaporation $\left(\mathrm{E}_{\mathrm{pan}}\right)$ from a US Class A pan situated $40 \mathrm{~m}$ from the site. Weekly results were averaged within the time periods; viz. Pre-RDI, RDI, Post$\mathrm{RDI}$, and postharvest. Leaf water potentials were measured at dawn and midday with a pressure chamber (Soilmoisture Equip- ment Corp., Santa Barbara, Calif.) during the RDI and post-RDI periods in Years 2 and 3.

Statistical analysis. Data were subjected to analysis of variance (ANOVA) using Genstat 5 (Lawes Agricultural Trust, Rothamstead Experimental Station, 1990). Treatments were irrigation and soil volumes. Soil volumes were fitted as linear and quadratic orthogonal polynomials; goodness of fit was determined by the significance of the linear and quadratic components $(P$ values). The mean value for full and deficit irrigation and their least significant difference (LSD) are presented. Nearest neighbor analyses failed to improve treatment comparisons indicating there were no site trends or autocorrelation between plots.

ROOT ESCAPES. When the compartments were excavated it was established that some roots had escaped through the plastic (Boland et al., 2000). Root cross-sectional area of escaped roots was included as a covariate in the ANOVA but was not significant.

Table 3. Effect of soil volume and irrigation on fruit number, total weight, and mean fruit weight at harvest in Years 2 to 4.

\begin{tabular}{|c|c|c|c|c|c|c|c|c|c|c|}
\hline \multirow{2}{*}{$\begin{array}{l}\text { Soil } \\
\text { vol } \\
\left(\mathrm{m}^{3}\right)\end{array}$} & \multicolumn{3}{|c|}{ Year 2} & \multicolumn{3}{|c|}{ Year 3} & \multicolumn{4}{|c|}{ Year 4} \\
\hline & No. & $\begin{array}{c}\text { Wt } \\
(\mathrm{kg})\end{array}$ & $\begin{array}{c}\text { MFW } \\
(\mathrm{g})\end{array}$ & No. & $\begin{array}{c}\mathrm{Wt} \\
(\mathrm{kg})\end{array}$ & $\begin{array}{c}\text { MFW } \\
(\mathrm{g})\end{array}$ & No. & & & $\begin{array}{c}\text { MFW } \\
(\mathrm{g})\end{array}$ \\
\hline & & & & & & & & & ovariat & \\
\hline 0.025 & 42.0 & 5.2 & 125.4 & 114.6 & 12.6 & 110.8 & 204.6 & 18.1 & 13.6 & 89.5 \\
\hline 0.06 & 55.0 & 6.4 & 117.9 & 142.8 & 16.2 & 113.0 & 159.0 & 16.3 & 15.6 & 102.8 \\
\hline 0.15 & 63.4 & 7.7 & 127.7 & 134.7 & 15.0 & 111.7 & 127.6 & 14.2 & 16.1 & 113.0 \\
\hline 0.4 & 72.1 & 9.1 & 130.9 & 129.3 & 15.1 & 116.9 & 125.9 & 14.5 & 16.5 & 115.3 \\
\hline 1.0 & 92.9 & 11.9 & 128.2 & 124.6 & 15.2 & 121.9 & 135.8 & 15.5 & 16.7 & 116.1 \\
\hline \multicolumn{11}{|c|}{$\begin{array}{l}\text { Significance of } \\
\text { contrast ( } P \text { value })\end{array}$} \\
\hline Linear & $<0.001$ & $<0.001$ & 0.365 & 0.442 & 0.339 & 0.014 & 0.004 & 0.277 & 0.033 & $<0.001$ \\
\hline Quadratic & 0.177 & 0.104 & 0.292 & 0.324 & 0.318 & 0.764 & $<0.001$ & 0.024 & 0.181 & $<0.001$ \\
\hline \multicolumn{11}{|c|}{ Volume $\times$ irrigation } \\
\hline$(P$ value $)$ & NS & NS & NS & NS & NS & NS & NS & NS & NS & NS \\
\hline \multicolumn{11}{|l|}{ Irrigation } \\
\hline Deficit & 68.8 & 8.2 & 121.7 & 128.0 & 14.8 & 115.8 & 158.9 & 16.3 & 15.6 & 107.3 \\
\hline Full & 61.3 & 7.8 & 130.3 & 130.4 & 14.9 & 114.0 & 142.2 & 15.1 & 15.8 & 107.4 \\
\hline $\mathrm{LSD}_{0.05}$ & NS & NS & 9.62 & NS & NS & NS & 18.76 & NS & NS & NS \\
\hline
\end{tabular}




\section{Results}

Fruit EXPANSION AND PRODUCTIVITY. In Year 2, the increase in fruit volume (fruit expansion) during the RDI period was related negatively to increasing soil volume (Table 2). During this period, deficit irrigation reduced fruit volume and there was an interaction between soil volume and irrigation treatment. Fruit expansion during the post-RDI period continued to be related negatively to soil volume. Fruit volume measurements were ended on 5 Mar. 1993 when harvest began. Differences in fruit maturity would influence fruit expansion measured in the postRDI period. Fruit from the larger soil volumes were harvested later and consequently fruit volume measurements underestimated final size.

Fruit expansion was not affected by soil volume or irrigation treatment in Years 3 and 4 (Table 2). There was an interaction between soil volume and irrigation treatment during the RDI period in Year 3. Post-RDI, fruit expansion ranged from a mean of $\approx 47 \mathrm{~cm}^{3}$ in Year 1 to $66 \mathrm{~cm}^{3}$ in Year 2 .
In Year 2, increasing soil volume had a positive effect on fruit number and weight (Table 3), as expected given the thinning strategy in Year 2. The fewer fruit for the small soil volumes accelerated maturity (demonstrated by fruit volume increase measurements). There was no effect of soil volume on mean fruit weight (MFW) at harvest.

There was no effect of treatment on fruit number or total weight in Year 3. There was a linear effect of soil volume on MFW in this year. In Year 4, there was a negative effect of increasing soil volume on fruit number. This difference was attributed to inaccuracies in thinning because trees in the smaller volumes had a greater number of concealed fruit clusters. Total fruit weight was affected by soil volume. Fruit number was included as a covariate for the analysis to demonstrate a positive linear effect of increasing soil volume on total fruit weight. Mean fruit weight was related positively to soil volume independent of fruit number.

Average yields were $\approx 20,37$, and $39 \mathrm{t} \cdot \mathrm{ha}^{-1}$ in Years 2, 3, and 4, respectively. Mean fruit weight for Years 2, 3, and 4 were 126, 115 and $107 \mathrm{~g}$ respectively.

Table 4. Effect of soil volume and regulated deficit irrigation (RDI) on relative tree water use $\left(\mathrm{L} \cdot \mathrm{mm}^{-1} \mathrm{E}_{\mathrm{pan}}\right)$ in Year 2, 3 and $4-$ pre-RDI, RDI, postRDI, and postharvest.

\begin{tabular}{|c|c|c|c|c|c|c|c|c|c|c|}
\hline \multirow{4}{*}{$\begin{array}{l}\text { Soil } \\
\text { vol } \\
\left(\mathrm{m}^{3}\right)\end{array}$} & \multicolumn{10}{|c|}{ Tree water use $\left(\mathrm{L} \cdot \mathrm{mm}^{-1} \mathrm{E}_{\mathrm{pan}}\right)$} \\
\hline & \multicolumn{10}{|c|}{ Year 2} \\
\hline & \multicolumn{3}{|c|}{ pre-RDI } & \multicolumn{3}{|c|}{ RDI } & \multicolumn{3}{|c|}{ post-RDI } & \multirow[b]{2}{*}{ Postharvest } \\
\hline & Mean & Deficit & $\overline{\text { Full }}$ & Mean & Deficit & $\overline{\text { Full }}$ & Mean & Deficit & $\overline{\text { Full }}$ & \\
\hline 0.025 & 0.98 & 1.09 & 0.88 & 1.03 & 0.79 & 1.27 & 1.81 & 2.11 & 1.50 & 1.63 \\
\hline 0.06 & 1.09 & 1.04 & 1.14 & 1.45 & 0.95 & 1.96 & 2.90 & 2.73 & 3.07 & 1.95 \\
\hline 0.15 & 1.46 & 1.23 & 1.69 & 1.87 & 1.09 & 2.65 & 3.61 & 3.29 & 3.94 & 2.84 \\
\hline 0.4 & 2.07 & 2.05 & 2.09 & 2.21 & 1.22 & 3.20 & 4.40 & 4.32 & 4.48 & 3.40 \\
\hline 1.0 & 2.04 & 2.04 & 2.04 & 2.38 & 1.23 & 3.54 & 4.43 & 4.22 & 4.63 & 3.01 \\
\hline \multicolumn{11}{|c|}{$\begin{array}{l}\text { Significance of } \\
\text { contrast ( } P \text { value })\end{array}$} \\
\hline Linear & $<0.001$ & & & $<0.001$ & & & $<0.001$ & & & $<0.001$ \\
\hline Quadratic & $<0.001$ & & & $<0.001$ & & & $<0.001$ & & & $<0.001$ \\
\hline \multicolumn{11}{|c|}{ Volume $\times$ irrigation } \\
\hline$(P$ value $)$ & $<0.001$ & & & $<0.001$ & & & 0.024 & & & NS \\
\hline \multicolumn{11}{|l|}{ Irrigation } \\
\hline Deficit & 1.49 & & & 1.05 & & & 3.33 & & & 2.53 \\
\hline Full & 1.57 & & & 2.52 & & & 3.53 & & & 2.60 \\
\hline \multirow[t]{4}{*}{$\mathrm{LSD}_{0.05}$} & 0.073 & & & 0.148 & & & NS & & & NS \\
\hline & \multicolumn{4}{|c|}{ Year 3} & & \multicolumn{5}{|c|}{ Year 4} \\
\hline & \multicolumn{4}{|c|}{ RDI } & & \multicolumn{3}{|c|}{ RDI } & & \\
\hline & pre-RDI & Mean & Deficit & $\overline{\text { Full }}$ & post-RDI & Mean & Deficit & $\overline{\text { Full }}$ & post-RDI & Postharvest \\
\hline 0.025 & 1.13 & 1.18 & 0.89 & 1.47 & 2.04 & 1.59 & 1.23 & 1.95 & 1.13 & 0.73 \\
\hline 0.06 & 1.26 & 1.52 & 1.05 & 1.99 & 3.34 & 2.28 & 1.31 & 3.24 & 1.92 & 0.99 \\
\hline 0.15 & 1.81 & 1.71 & 1.12 & 2.31 & 2.86 & 2.27 & 1.12 & 3.42 & 2.33 & 1.59 \\
\hline 0.4 & 1.97 & 1.97 & 1.31 & 2.63 & 3.64 & 2.20 & 1.43 & 2.98 & 2.75 & 1.72 \\
\hline 1.0 & 1.81 & 2.16 & 1.17 & 3.16 & 4.00 & 2.37 & 1.38 & 3.37 & 2.72 & 1.81 \\
\hline \multicolumn{11}{|c|}{$\begin{array}{l}\text { Significance of } \\
\text { contrast ( } P \text { value })\end{array}$} \\
\hline Linear & $<0.001$ & $<0.001$ & & & $<0.001$ & $<0.001$ & & & $<0.001$ & $<0.001$ \\
\hline Quadratic & $<0.001$ & $<0.001$ & & & 0.011 & 0.008 & & & $<0.001$ & $<0.001$ \\
\hline \multicolumn{11}{|c|}{ Volume $\times$ irrigation } \\
\hline$(P$ value $)$ & NS & $<0.001$ & & & NS & $<0.001$ & & & NS & NS \\
\hline \multicolumn{11}{|l|}{ Irrigation } \\
\hline Deficit & 1.47 & 1.11 & & & 3.13 & 1.29 & & & 2.11 & 1.32 \\
\hline Full & 1.72 & 2.31 & & & 3.22 & 2.99 & & & 2.23 & 1.41 \\
\hline $\mathrm{LSD}_{0.05}$ & 0.214 & 0.151 & & & NS & 0.122 & & & NS & NS \\
\hline
\end{tabular}


Tree water uSE. Tree water use was calculated over four periods: pre-RDI—canopy development; RDI—stage 2 of fruit growth, rapid vegetative growth; post-RDI—rapid fruit growth (Stage 3); postharvest-following harvest.

In Year 2, increasing soil volume was related positively to tree water use (Table 4). Deficit-irrigated trees used less water than fully irrigated trees during the pre-RDI and RDI periods. There was an interaction between soil volume and irrigation treatment in the pre-RDI, RDI, and post-RDI periods.

Tree water use was related positively to increasing soil volume during all periods in Years 3 and 4 (Table 4). Water use of deficitirrigated trees was less than fully irrigated trees in Years 3 (preRDI and RDI periods) and 4 (RDI period). There was an interaction between soil volume and irrigation treatment during RDI in Years 3 and 4.

Patterns of relative seasonal tree water use [(litres per millimeter pan evaporation $\left.\left(\mathrm{L} \cdot \mathrm{mm}^{-1} \mathrm{E}_{\mathrm{pan}}\right)\right]$ were similar to those determined previously for a lysimeter experiment (Boland et al., 1993a). Average water use of trees under full irrigation increased from $\approx 1.6$ to $1.7 \mathrm{~L} \cdot \mathrm{mm}^{-1} \mathrm{E}_{\text {pan }}[$ Crop Factor $(\mathrm{CF})=0.40-0.43]$ in the pre-RDI period to 2.3 to $3.0 \mathrm{~L} \cdot \mathrm{mm}^{-1} \mathrm{E}_{\mathrm{pan}}(\mathrm{CF}=0.58-0.75)$ during RDI. In the post-RDI period, water use was 2.2 to 3.5 $\mathrm{L} \cdot \mathrm{mm}^{-1} \mathrm{E}_{\mathrm{pan}}(\mathrm{CF}=0.55-0.88)$, declining to 1.4 to $2.6(\mathrm{CF}=$ $0.35-0.65) \mathrm{L} \cdot \mathrm{mm}^{-1} \mathrm{E}_{\mathrm{pan}}$ postharvest. Deficit-irrigated trees demonstrated a similar pattern, except during RDI when water use was 1.0 to $1.3 \mathrm{~L} \cdot \mathrm{mm}^{-1} \mathrm{E}_{\text {pan }}(\mathrm{CF}=0.25-0.33)$. Maximum tree water use of $4.63 \mathrm{~L} \cdot \mathrm{mm}^{-1} \mathrm{E}_{\mathrm{pan}}(\mathrm{CF}=1.16)$ was measured during the post-RDI period for trees under full irrigation grown in $1.0 \mathrm{~m}^{3}$ of soil. Crop factors for this treatment (considered a control) were similar to those of the control in a lysimeter experiment (Boland et al., 1993b).

Water Relations. In Year 2, during RDI there was a quadratic effect of soil volume on leaf water potential at dawn and no effect at midday (Table 5). Deficit-irrigated trees had more negative water potentials than fully irrigated trees at midday during RDI. Post-RDI, there was a linear effect of soil volume at dawn on the third and fourth measurement dates.

Table 5. Effect of soil volume and irrigation on leaf water potentials (-MPa) in Years 2 and 3 during the regulated deficit irrigation (RDI) and postRDI periods.

\begin{tabular}{|c|c|c|c|c|c|c|c|c|c|c|c|c|}
\hline \multirow{5}{*}{$\begin{array}{l}\text { Soil } \\
\text { vol } \\
\left(\mathrm{m}^{3}\right)\end{array}$} & \multicolumn{12}{|c|}{ Leaf water potential $(-\mathrm{MPa})$} \\
\hline & \multicolumn{4}{|c|}{ RDI } & \multicolumn{7}{|c|}{ post-RDI } & \\
\hline & \multicolumn{11}{|c|}{ Year 2} & \\
\hline & \multicolumn{2}{|c|}{$5 / 1 / 93$} & \multicolumn{2}{|c|}{$14 / 1 / 93$} & \multicolumn{2}{|c|}{$10 / 2 / 93$} & \multicolumn{2}{|c|}{$18 / 2 / 93$} & \multicolumn{2}{|c|}{$4 / 3 / 93$} & \multirow{2}{*}{$\begin{array}{l}10 / 3 / 93 \\
\text { Midday }\end{array}$} & \\
\hline & Dawn & Midday & Dawn & Midday & Dawn & Midday & Dawn & $\overline{\text { Midday }}$ & Dawn & Midday & & \\
\hline 0.025 & 0.51 & 1.69 & 0.43 & 2.05 & 0.40 & 1.89 & 0.40 & 1.92 & 0.46 & 1.54 & 1.68 & \\
\hline 0.06 & 0.52 & 1.51 & 0.39 & 2.04 & 0.44 & 1.95 & 0.40 & 1.68 & 0.50 & 1.47 & 1.65 & \\
\hline 0.15 & 0.69 & 1.79 & 0.56 & 2.18 & 0.41 & 2.07 & 0.38 & 1.73 & 0.47 & 1.48 & 1.69 & \\
\hline 0.4 & 0.92 & 1.80 & 0.79 & 2.81 & 0.47 & 1.94 & 0.43 & 1.71 & 0.49 & 1.53 & 1.59 & \\
\hline 1.0 & 0.59 & 1.68 & 0.52 & 2.09 & 0.48 & 2.31 & 0.43 & 1.91 & 0.50 & 1.40 & 1.70 & \\
\hline \multicolumn{13}{|c|}{$\begin{array}{l}\text { Significance of } \\
\text { contrast ( } P \text { value })\end{array}$} \\
\hline Linear & 0.532 & 0.710 & 0.315 & 0.831 & 0.033 & 0.081 & 0.069 & 0.315 & 0.394 & 0.289 & 0.862 & \\
\hline Quadratic & 0.001 & 0.187 & 0.004 & 0.235 & 0.383 & 0.627 & 0.576 & 0.142 & 0.967 & 0.566 & 0.380 & \\
\hline \multicolumn{13}{|c|}{ Volume $\times$ irrigation } \\
\hline \multicolumn{13}{|l|}{ Irrigation } \\
\hline Deficit & 0.69 & 1.79 & 0.60 & 2.18 & 0.44 & 2.09 & 0.40 & 1.81 & 0.49 & 1.49 & 1.69 & \\
\hline Full & 0.61 & 1.60 & 0.47 & 2.03 & 0.44 & 1.98 & 0.42 & 1.77 & 0.47 & 1.48 & 1.64 & \\
\hline \multirow{4}{*}{$\mathrm{LSD}_{0.05}$} & NS & 0.198 & NS & 0.176 & NS & NS & NS & NS & NS & NS & NS & \\
\hline & \multicolumn{12}{|c|}{ Year 3} \\
\hline & \multicolumn{2}{|c|}{$8 / 12 / 93$} & \multicolumn{2}{|c|}{$20 / 12 / 93$} & \multicolumn{2}{|c|}{$14 / 1 / 94$} & \multicolumn{2}{|c|}{$3 / 2 / 94$} & \multicolumn{2}{|c|}{$22 / 2 / 94$} & \multicolumn{2}{|c|}{$3 / 3 / 94$} \\
\hline & Dawn & Midday & Dawn & $\overline{\text { Midday }}$ & Dawn & $\overline{\text { Midday }}$ & Dawn & $\overline{\text { Midday }}$ & Dawn & $\overline{\text { Midday }}$ & Dawn & Midday \\
\hline 0.025 & 0.41 & 1.68 & 0.39 & 1.73 & 0.45 & 1.65 & 0.41 & 2.17 & 0.31 & 1.92 & 0.29 & 1.62 \\
\hline 0.06 & 0.38 & 1.64 & 0.33 & 1.61 & 0.41 & 1.61 & 0.35 & 1.82 & 0.30 & 1.85 & 0.28 & 1.61 \\
\hline 0.15 & 0.44 & 1.76 & 0.33 & 1.69 & 0.45 & 1.66 & 0.36 & 1.83 & 0.30 & 1.75 & 0.28 & 1.60 \\
\hline 0.4 & 0.55 & 1.67 & 0.45 & 1.78 & 0.62 & 1.74 & 0.33 & 1.73 & 0.27 & 1.69 & 0.27 & 1.60 \\
\hline 1.0 & 0.71 & 1.87 & 0.52 & 1.89 & 0.46 & 1.75 & 0.34 & 1.72 & 0.34 & 1.74 & 0.32 & 1.65 \\
\hline \multicolumn{13}{|c|}{$\begin{array}{l}\text { Significance of } \\
\quad \text { contrast ( } P \text { value })\end{array}$} \\
\hline Linear & 0.004 & 0.039 & 0.015 & 0.040 & 0.584 & 0.244 & 0.064 & 0.024 & 0.219 & 0.216 & 0.110 & 0.578 \\
\hline Quadratic & 0.776 & 0.492 & 0.859 & 0.909 & 0.073 & 0.533 & 0.049 & 0.066 & 0.023 & 0.131 & 0.222 & 0.434 \\
\hline $\begin{array}{l}\text { Volume } \times \text { irrig } \\
\quad(P \text { value })\end{array}$ & NS & 0.031 & NS & NS & NS & NS & NS & NS & NS & NS & NS & 0.044 \\
\hline Irrigation & & & & & & & & & & & & \\
\hline Deficit & 0.55 & 1.76 & 0.48 & 1.82 & 0.55 & 1.78 & 0.37 & 1.91 & 0.30 & 1.82 & 0.29 & 1.60 \\
\hline Full & 0.45 & 1.69 & 0.32 & 1.66 & 0.40 & 1.58 & 0.35 & 1.80 & 0.31 & 1.76 & 0.29 & 1.61 \\
\hline $\mathrm{LSD}_{0.05}$ & NS & NS & 0.100 & 0.158 & 0.135 & 0.159 & NS & NS & NS & NS & NS & NS \\
\hline
\end{tabular}


In Year 3, leaf water potentials were more negative with increasing soil volume for the first two dates of the RDI period (Table 5). On the third date there was no effect of soil volume on leaf water potential. Leaf water potentials were more negative for the deficit-irrigated trees on the second and third dates. Post-RDI, there was no effect of soil volume or irrigation treatment.

\section{Discussion}

The discussion relies on the presented ANOVA for soil volume and irrigation. However, it is necessary to evaluate the likely effect of root escape (Boland et al., 2000) (Fig. 1) on measured parameters to determine which data can be interpreted with certainty.

Fruit yield was unrelated to RCA (data not presented) indicating that escaped roots did not effect fruit growth or productivity. Therefore, while roots outside the compartment increased top weight (Boland et al., 2000), they did not appear to influence fruit production.

It is difficult to determine the contribution of root escapes to tree water use. In Year 2, this contribution was likely to be minimal, as the trees were young and filling the soil volume. In contrast, wet conditions in Year 3 during the RDI period (rainfall $205 \mathrm{~mm}$ for October, November, and December compared with average of $119 \mathrm{~mm}$ ) would likely have resulted in wet soil outside the compartments. Crop factors during this and the post-RDI periods were typical for trees in the largest volumes suggesting that water outside compartments was not of significance. Contribution may have occurred for trees in the small volumes during the RDI period. In Year 4, conditions during the RDI period were dry (rainfall $35 \mathrm{~mm}$ for October, November, and December compared with average of $119 \mathrm{~mm}$ ) and there was little available water outside the compartments. Water use and water relations results are most likely reliable during the RDI and postharvest periods in this year. Rainfall was high in the post-RDI period (rainfall $104 \mathrm{~mm}$ for January compared with average of $30 \mathrm{~mm}$ ). Small crop factors during this period may be a result of contribution of water from outside. Water use results are considered unreliable during this period. The effect of soil volume and irrigation on production, water use and water relations are discussed, considering the potential influences of root escapes.

Both soil volume and RDI affected fruit growth in Year 2 (Table 2). In Years 3 and 4, fruit size was reduced on trees in the 0.025 and $0.06 \mathrm{~m}^{3}$ soil volumes. This decrease occurred with similar fruit density for all volumes and was not an effect of water stress. Several authors (Mandre et al., 1995; Myers and Savelle, 1990; Williamson and Coston, 1990) reported no effect of root restriction on fruit size and growth rate of peach. However, fruit size reduction was demonstrated for peaches in $5 \mathrm{~L}$ containers (Erez et al., 1992) and attributed to the incapacity of the root system to support the remaining fruit.

Yield efficiency $\left(\mathrm{g} \cdot \mathrm{cm}^{-2}\right.$ TCA) is generally not influenced by restricted volume (Mandre et al., 1995; Myers and Savelle, 1990; Williamson and Coston, 1990; Williamson et al., 1992) and was also the case in our experiment (data not presented). In a highdensity orchard, estimates of yield based on TCA become less useful once the tree has filled its allotted space. From then, yield per tree is the most valid estimate of tree productivity as highdensity orchards rely on efficient utilization of the orchard area. It was not until Year 4 that all trees filled their space. In this year, all trees were thinned uniformly, and as a result, yield of trees in the two smallest volumes was reduced (when fruit number was included as a covariate) (Table 3). Myers and Savelle (1990) demonstrated increased yield with root restriction in contrast to reductions recorded in apple [Malus sylvestris (L.) Mill var. domestica (Borkh.) Mansf.] (Bar-Yosef et al., 1988) and peach (Erez et al., 1992; Ran et al., 1994). The effect on yield will depend largely on severity of root restriction and amount of vigor. These results suggest that the contribution from root escapes was insufficient to maintain productivity in the two smallest volumes.

In all years, trees in small soil volumes used less water (Table 4). This effect has been demonstrated for tomato (Lycopersicon esculentum Mill.) (Hameed et al., 1987), apple (Bar-Yosef et al., 1988), and peach (Proebsting et al., 1989). Ran et al. (1992) proposed that restricted volumes reduce water uptake due to reduced root and top weight, but root volume did not influence the flux of water (uptake per unit root weight). There was little difference in total weight of roots at the completion of the experiment indicating that root mass was not a critical factor (Boland et al., 2000). These results suggest that differences in water use were caused either by variation in root composition (proportion of fibrous and structural roots) and/or canopy size (thickness and density) or function (conductance). In Year 4, although all trees had filled their surface canopy area, fruit size was reduced in the small soil volumes (Table 3). This may be attributed to a decline in canopy thickness and density of trees in the small soil volumes. Reduced canopy function (as measured by leaf conductance) would also limit tree water use. Proebsting et al. (1989) demonstrated a decline of both conductance and water use of peach in nonfruiting trees, however, conductance was not reduced consistently with root restriction in our experiment (data not presented). It is therefore probable that decreased canopy density and thickness limited carbohydrate production and water use. Root escapes may have influenced water use, although results indicate that water use was most closely related to canopy demand. Reduced water use of the smallest volumes was demonstrated during all periods (when contribution of escaped roots would have been minimal and also when external soil was moist).

RDI reduced water use during the RDI period in all years as demonstrated in a lysimeter experiment (Table 4) (Boland et al., 1993a, 1993b). There was an interaction between RDI and soil volume on water use during the RDI period in all years.

A decline in leaf water potential under root restriction has been demonstrated previously (Dubik et al., 1990; Hameed et al., 1987; Tschaplinski and Blake, 1985). In our experiment, there was an inconsistent effect of soil volume on leaf water potential being unaffected in a majority of cases similar to the observation of Proebsting et al. (1989) (Table 5). During the early stages of the post-RDI period in Year 2 and the RDI period in Year 3, trees in the larger soil volumes had lower leaf water potentials. This effect ceased once irrigations were adjusted for individual soil volumes. It is not possible to determine the influence of root escapes on leaf water potentials, although roots that accessed water outside the compartments would cause an increase in leaf water potentials. Efficient irrigation of the smallest volumes would have a similar effect. RDI caused a reduction in leaf water potential during the RDI period in Year 3 as demonstrated previously (Table 5) (Boland et al., 1993b; Chalmers et al., 1986).

In summary, RDI reduced vegetative growth, maintained productivity, and increased water use efficiency as demonstrated previously for stone fruit (Lampinen et al., 1995; Mitchell and Chalmers, 1982; Williamson and Coston, 1990). RRV was effective in controlling vegetative vigor in all years. A smaller response in Year 3 was attributed to higher than average rainfall 
during the RDI period and escaped roots from the smaller compartments.

Tree water use was reduced under root restriction as a consequence of canopy demand rather than leaf function. Similar water use and leaf water potential responses suggest that escaped roots were not a significant factor during the RDI periods of Years 3 and 4. Root restriction reduced fruit size of trees in the two smallest volumes despite maintenance of tree water relations. It would appear that root capacity was not limiting rather the canopy (density and thickness) restricted production of carbohydrates which were insufficient to maintain fruit growth. Root restriction caused a response independent of water relations and mineral nutrition. Several authors (Mandre et al., 1995; Richards, 1986; Richards and Rowe, 1977a, 1977b; Rieger and Marra, 1994) have hypothesized that a root induced signal is involved in the response and our data support this proposal.

Root restriction is a viable alternative for control of vegetative growth, however, the physiological response of trees to RRV requires further investigation. Minimum soil volumes required to maintain productivity and fruit size are $\approx 150 \mathrm{~L}\left(0.15 \mathrm{~m}^{3}\right)$ per tree.

There was an interaction between root volume and irrigation for tree water use during the RDI period for all years. There were few other parameters where an interaction was isolated indicating that response to water stress and root volume are relatively independent. The exception is for water use under conditions of stress. Water stressed (RDI) trees used similar amounts of water regardless of available soil volume. This finding indicates that water stress will limit water use even for trees with large root volumes and has important implications for the application of RDI in the field. Although it will take longer to develop water stress of a tree with a large root system, RDI will be effective in reducing water use and restricting vegetative growth. Results from this experiment suggest that the RDI response in the Goulburn Valley, Australia is achieved by a combination of restricted root volume (Richards and Rowe, 1977a, 1977b) and the development of sufficient levels of water stress (Girona et al., 1993; Jerie et al., 1989).

\section{Literature Cited}

Bar-Yosef, B., S. Schwartz, T. Markovich, B. Lucas, and R. Assaf. 1988. Effect of root volume and nitrate solution concentration on growth, fruit yield and temporal $\mathrm{N}$ and water uptake rates by apple trees. Plant and Soil 107:49-56.

Boland, A.M., P.D. Mitchell, and P.H. Jerie. 1993a. Effect of saline water combined with restricted irrigation on peach tree growth and water use. Austral. J. Agr. Res. 44:799-816.

Boland, A.M., P.D. Mitchell, P.H. Jerie, and I. Goodwin. 1993b. Effect of regulated deficit irrigation on tree water use and growth of peach. J. Hort. Sci., 68:261-274.

Boland, A.M., P.D. Mitchell, I. Goodwin, and P.H. Jerie. 1994. The effect of soil volume on young peach tree growth and water use. J. Amer. Soc. Hort. Sci. 119:1157-1162.

Boland, A.M., P.H. Jerie, P.D. Mitchell, I. Goodwin, and D.J. Connor. 2000. Long-term effects of soil volume and irrigation on peach. I. Growth and nutrition. J. Amer. Soc. Hort. Sci. 125(1):xxx-xxx.

Chalmers, D.J., G. Burge, P.H. Jerie, and P.D. Mitchell. 1986. The mechanism of regulation of 'Bartlett' pear fruit and vegetative growth by irrigation withholding and regulated deficit irrigation. J. Amer. Soc.
Hort. Sci. 111:904-907.

Dubik, S.P., D.T. Krizek, and D.P. Stimart. 1990. Influence of root zone restriction on mineral element concentration, water potential, chlorophyll concentration, and partitioning of assimilate in spreading euonymus [E. kiautschovica Loes. 'Sieboldiana']. J. Plant. Nutr. 13:677-99.

Erez, A., Y. Ran, and B. Bar-Yosef. 1992. The effect of restricted root volume on the development, yield and dry-matter partitioning in young fruiting peach trees. Acta Hort. 322:199-214.

Girona, J., M. Mata, D.A. Goldhamer, R.S. Johnson, and T.M. DeJong. 1993. Patterns of soil and tree water status and leaf functioning during regulated deficit irrigation scheduling in peach. J. Amer. Soc. Hort. Sci. 118:580-586.

Hameed, M.A., J.B. Reid, and R.N. Rowe. 1987. Root confinement and its effects on the water relations, growth and assimilate partitioning of tomato (Lycopersicon esculentum Mill.) Ann. Bot. 59:685-692.

Jerie, P.H., B. van den Ende, and I. Dann. 1989. Managing tree vigour and fruitfulness in deciduous orchards. Acta Hort. 240:127-134.

Lampinen, B.D., K.A. Shackel, S.M. Southwick, B. Olson, J.T. Yeager, and D. Goldhamer. 1995. Sensitivity of yield and fruit quality of French prune to water deprivation at different fruit growth stages. J. Amer. Soc. Hort. Sci. 120:139-147.

Mandre, O., M. Rieger, S.C. Myers, R. Seversen, and J.L. Regnard. 1995. Interaction of root confinement and fruiting in peach. J. Amer. Soc. Hort. Sci. 120:228-234.

Mitchell, P.D. and D.J. Chalmers. 1982. The effect of reduced water supply on peach tree growth and yield. J. Amer. Soc. Hort. Sci. 107:853-856.

Mitchell, P.D., D.J. Chalmers, and L.A.G. Van Heek. 1983. The use of temporary trees in a hedgerow planting of peach trees. J. Amer. Soc. Hort. Sci. 108:681-685.

Myers, S.C. 1992. Root restriction of apple and peach with in-ground fabric containers. Acta Hort. 322:215-219.

Myers, S.C. and A. Savelle. 1990. Effect of in-ground fabric containers on growth and fruiting of peach and apple. Proc. Southeastern Professional Fruit Workers Conf. 4:1-3.

Proebsting, E.L., P.H. Jerie, and J.L. Irvine. 1989. Water deficits and rooting volume modify peach tree growth and water relations. J. Amer. Soc. Hort. Sci. 114:368-372.

Ran, Y., B. Bar-Yosef, and A. Erez. 1992. Root volume influence on dry matter production and partitioning as related to nitrogen and water uptake rates by peach. J. Plant Nutr. 15:713-726.

Ran, Y., R. Habib, B. Bar-Yosef, and A. Erez. 1994. Root volume effects on nitrogen uptake and partitioning in peach trees. Agron. J. 86:530 534.

Richards, D. 1986. Tree growth and productivity-The role of roots. Acta Hort. 175: 27-36.

Richards, D. and R.N. Rowe. 1977a. Root-shoot interactions in peach: The function of the root. Ann. Bot. 41:1211-1216.

Richards, D. and R.N. Rowe, R.N. 1977b. Effects of the root restriction, root pruning and 6-benzylamino-purine on the growth of peach seedlings. Ann. Bot. 41:729-740.

Rieger, M. and F. Marra. 1994. Responses of young peach trees to root confinement. J. Amer. Soc. Hort. Sci. 119:223-228.

Tschaplinski, T.J. and T.J. Blake, T.J. 1985. Effects of root restriction on growth correlations, water relations, and senescence of alder seedlings. Physiol. Plant. 64:167-76.

Williamson, J.G. and D.C. Coston. 1990. Planting method and irrigation rate influence vegetative and reproductive growth of peach planted at high density. J. Amer. Soc. Hort. Sci. 115:207-212.

Williamson, J.G., D.C. Coston, and J.A. Cornell. 1992. Root restriction affects shoot development of peach in a high-density orchard. J. Amer. Soc. Hort. Sci. 117:362-367. 